\title{
Association of Genital Chlamydia trachomatis Infection with Female Infer- tility, Study in a Tertiary Care Hospital in Eastern India
}

\author{
Mallika Ghosh ${ }^{1}$, Subhadip Choudhuri ${ }^{2}$, Reena Ghosh Ray ${ }^{3}$, Basudev Bhattacharya $^{2}$ and \\ Sujata Bhattacharya ${ }^{3, *}$
}

${ }^{I}$ National Institute of Cholera \& Enteric Diseases, Kolkata 700010, India; ${ }^{2}$ Department of Biochemistry, Institute of Post Graduate Medical Education \& Research, Kolkata 700020, India; ${ }^{3}$ Department of Microbiology, R. G. Kar Medical College, Kolkata 700004, India

\begin{abstract}
Background: Chlamydia trachomatis is recognized as one of the most common sexually transmitted pathogen in the world. 50-80\% of infected females are asymptomatic. These untreated women are at risk of developing chronic sequelae leading to tubal pathology causing infertility. Infertility is defined as 1 year of unprotected intercourse without pregnancy. It may be primary or secondary. Aim: To find out the association of genital Chlamydia trachomatis infection with female infertility. Materials and Methodology: This case control study has been carried out in collaboration with R. G. Kar Medical College and Institute of Post Graduate Medical Education \& Research, India, between July 2012 and June 2013. 40 infertile and 40 pregnant women were enrolled by purposive sampling as per inclusion and exclusion criteria. ELISA test was performed to detect serum IgG and IgA antibody against recombinant analogs of MOMP and 3 different PCR assays were done targeting MOMP and rRNA DNA from DNA extracted from first void urine. Results: IgG seropositivity was significantly higher $(15 \%$ vs $0 \%, P=.0255)$ in cases than controls, though there was no significant difference in the proportion of IgA seropositivity among 2 groups (12.5\% vs 2.5\%, $P=0.2007)$. Out of 80 samples 2 samples showed the production of amplicons with R1 - R2 primers. Only 1 sample gave positive result with production of amplicons with all the 3 primers used (R1 - R2, CT0005 - CT06 and JM15 - JM16). Conclusion: Persistent C. trachomatis infection must be recognized as a risk factor of infertility in this region of India. The low PCR positivity in FVU sample helps to conclude the diagnostic utility of serological tests in screening of infertile women.
\end{abstract}

Keywords: Chlamydia trachomatis, ELISA, Infertility, PCR.

\section{INTRODUCTION}

Chlamydia trachomatis is an obligate intracellular bacterium. It is currently recognized as one of the most common sexually transmitted pathogen. World Health Organization (WHO) estimates that, globally 98 million adults were infected by $C$. trachomatis at any point of time in the year 2005 [1]. According to U.S. Centre for Disease Control (CDC) and Prevention STD surveillance report 2007, $1,030,911$ Chlamydia trachomatis infection were reported in 2006, which increased to about 1.24 millions in the year 2009 [2,3]. Due to lack of screening in some population and little public awareness there is substantial underreporting. CDC estimates that 2-3 million new cases occur every year [3].

Acute genital tract infections due to Chlamydia trachomatis serovars $\mathrm{D}$ through $\mathrm{K}$ are associated with many syndromes like cervicitis, salpingitis, acute urethral syndrome and endometritis in females or urethritis, proctitis and epididymitis in males [4]. These infections can be treated and controlled, if proper and timely medical intervention is

*Address correspondence to this author at the Department of Microbiology, R. G. Kar Medical College, Kolkata 700004, India;

Tel: +919836068434; E-mails: mallika.kolkata@gmail.com,

bbasudev@rediffmail.com made. These may lead to major complications like chronic pelvic pain, pelvic inflammatory disease (PID), ectopic pregnancy and tubal factor infertility. According to different studies $50-80 \%$ of female patients with genital Chlamydia trachomatis infection lack symptom [5]. Thus a large reservoir of infected people continue to transmit it sexually and also is at risk of different sequelae in any given population. It is primarily a woman's health care issue since the manifestations and consequences are more damaging to the reproductive health in woman than in man.

Infertility is defined as 1 year of unprotected intercourse without pregnancy. It is further classified as primary and secondary infertility. Primary infertility is a term used to designate those couples who have never conceived, whereas secondary infertility is a term used for a condition where a prior pregnancy, although not necessarily a live birth has occurred [6]. Infertility has a great socio-psychological impact. According to a joint WHO-DHS comparative report in 2004, 60-80 million couples suffer from infertility worldwide [7]. Prevalence varies across different regions of the world and is estimated to affect $8 \%$ to $12 \%$ of couples worldwide [8]. Overall prevalence of primary infertility in India is between $3.9 \%$ and $16.8 \%$ [7].

The target cells of genital tract infections in women are squamo-columnar epithelial cells of the endocervix and upper genital tract [4]. Infection of reproductive tract epithe- 
lium results in production of interleukin (IL)-1, tumor necrosis factor- $\alpha$ (TNF- $\alpha)$, IL-8, growth-related oncogene (GRO)a, granulocyte-macrophage colony stimulating factor (GMCSF), and IL-6, which induce increased expression of endothelial adhesion molecules that aid in the attraction of immune cells [4, 9-11]. Resident tissue macrophages also contribute to early release of cytokines and chemokines. Infected epithelial cells release matrix metalloproteases (MMPs) which contribute to tissue proteolysis and remodeling. At the time of reinfection, host cells' release of chemokines leads to recruitment of Chlamydia specific immune cells that rapidly amplify the response [12]. Chlamydial endometritis and salpingitis induces antibodies to heat shock proteins (hsps), particularly, hsp $60[9,13]$. As Chlamydia shares epitopes with human hsps, it may cause an autoimmune response [4, $14,15]$. Reticulate bodies may escape the immune response, and causes persistent infection. Host, virulence of the pathogen and environment are the determining factors for the clearance or persistence of the infection [16]. Formation of new elementary bodies from reticulate bodies can induce immune response and inflammatory reactions resulting in a cyclic process of scarring of the infected tissue leading to partial or total obliteration of the fallopian tubes causing tubal factor infertility or sub infertility [12, 14, 17]. After one episode of Pelvic Inflammatory Disease (PID) the ratio of infertility has been estimated to be $25 \%$ which increases to $50 \%$ and $75 \%$ after $2^{\text {nd }}$ and $3^{\text {rd }}$ episodes respectively [14].

Chlamydial PID is one of the most common preventable causes of tubal factor infertility and adverse pregnancy outcomes. Exact scenario about prevalence of genital Chlamydia trachomatis infection and its sequelae is scarce in developing countries as reliable tests are too expensive and complex to carry out as routine screening methods.

The present study was conducted to find out the association of genital tract Chlamydia trachomatis infection with female infertility by evaluating the magnitude of infection in infertile and pregnant women.

\section{MATERIALS AND METHODOLOGY}

The present case control study has been carried out in collaboration with Department of Microbiology and Department of Gynaecology \& Obstetrics (G \& O), R. G. Kar medical college, Kolkata 700004, India and Biochemistry research wing, Department of Biochemistry, Institute of Post Graduate Medical Education \& Research, Kolkata 700020, India, from July 2012 to June 2013.

Infertile women (cases $\mathrm{n}_{1}=40$ ) attending Gynaecology Out Patient Department (OPD) were enrolled by purposive sampling as per inclusion and exclusion criteria. Sample size was determined by the Fleiss method [18] with continuity correction from Open Epi, Version 3, open source calculator-SSCC considering the study of Malik et al., 2006 as reference [19]. Cases of primary and secondary female infertility with or without history of pelvic inflammatory disease (PID), associated laparoscopic findings like tubal blockage, adhesion etc. were included in the study. Diagnosed cases of female infertility due to other reasons such as endometriosis, polycystic ovarian disease, PID due to other causes, mechanical causes of infertility (previous surgery, dilatation \& curettage, congenital abnormalities etc.), and medical disor- ders were excluded from the present study. Pregnant women $\left(\mathrm{n}_{2}=40\right)$ attending Antenatal clinic were included in the study as controls. The cases and controls were matched according to their mean age and socio economic status (as per modified B.G. Prasad's scale, 2013) [20]. Institutional ethics committee (IEC) clearance was obtained. Informed consent form duly signed by all the subjects was obtained after explanation of purpose of study.

\section{Laboratory Investigations}

\section{Enzyme Linked Immuno Sorbent Assay (ELISA)}

Serum samples were tested for the detection of $\mathrm{IgG}$ and IgA antibodies to $C$. trachomatis by using commercially available kits (DS-EIA-ANTI-CHLAMYDIA TR-A Kit/ DS-EIA-ANTI-CHLAMYDIA TR-G Kit, DSI, Germany). The antigens used in these assays are recombinant analog of major outer membrane protein (MOMP) of C. trachomatis. The test was validated according to the kit manual. The optical density was read at $450 \mathrm{~nm}$ using a microplate reader. Cut off value was calculated according to the manufacturer's instructions.

\section{Polymerase Chain Reaction}

$15 \mathrm{ml}$ of first void urine was collected aseptically in a sterile falcon (USA) polypropelene centrifuge tube and stored immediately at $4^{\circ} \mathrm{C}$. None of the patients had received antibiotic treatment 4 weeks prior to the visit and were eligible if they had not voided urine during the last 2 hours. The samples were centrifuged at $1400 \mathrm{~g}$ for 20 minutes. The supernatant was discarded and the pellet was dissolved in $1 \mathrm{x}$ Phosphate Buffer Saline (PBS; pH 7.4) solution and stored at $-20^{\circ} \mathrm{C}$ until DNA extraction was done.

DNA was extracted according to the modified method described by Fallah et al., 2005 [21]. In brief, the stored urine sample was centrifuged at $8900 \mathrm{~g}$ for 5 minutes in a microcentrifuge tube at room temperature. The pellet was dissolved in $500 \mu 1$ of lysis buffer [pH 7.5, 50mM TrisEDTA (sigma, USA), $1 \% \operatorname{SDS}$ (sigma, USA)] and incubated at $55^{\circ} \mathrm{C}$ in a dry bath for overnight. After overnight incubation the lysed cells in buffer was centrifuged at $8900 \mathrm{~g}$ for 10 minutes in a microcentrifuge. The pellet was dissolved in $200 \mu 1$ of Tris EDTA Glucose buffer [pH 7.0, 25mM Tris (sigma, USA), 10mM EDTA (Sigma, USA), 50mM glucose (Sigma, USA), $20 \mu 1$ Proteinase K (20mg/ml, Sigma, USA) ] and $200 \mu 1$ of Absolute ethanol (Sigma, USA, $95-100 \%$ ). Then it was mixed thoroughly by vortexing for 15 seconds and was incubated at $37^{\circ} \mathrm{C}$ for 10 minutes. The lysate was transferred into a HiElute Miniprep Spin column (MB505 HiPura Bacterial and Yeast Genomic DNA Purification Spin Kit, Himedia, India) and centrifuged at $8900 \mathrm{~g}$ for 1 minute. Further DNA was extracted according to instructions of manufacturer (MB505 HiPura Bacterial and Yeast Genomic DNA Purification Spin Kit, HiMedia India). The eluted DNA was identified by electrophoresis on $1 \%$ agarose gel, stained with $0.5 \mathrm{mg} / \mathrm{ml}$ ethidium bromide, in $1 \mathrm{X}$ TrisAcetate EDTA buffer ( $\mathrm{pH}$ 8.0). The purity of extracted DNA was determined by measuring the quotient of the absorption data measured at $260 \mathrm{~nm}$ and $280 \mathrm{~nm}$ by using a UV visible double beam spectrophotometer. 
3 different PCR assays targeted a major outer membrane protein (MOMP) and rRNA DNA. For analysing MOMP and rRNA DNA, $100 \mathrm{ng}$ DNA was amplified with the use of 1 unit DNA polymerase (Fermentus) in PCR reaction mixture, containing $1 \mathrm{X}$ PCR buffer $(10 \mathrm{mM}$ Tris, $\mathrm{pH} 8.3,50 \mathrm{mM}$ $\mathrm{KCl}, 2.5 \mathrm{mM} \mathrm{MgCl} 2,0.01 \%$ gelatin), $2 \mathrm{mM} \mathrm{MgCl} 2,0.25 \mathrm{mM}$ each dNTP, 20 picomoles each forward and reverse primers. The primer sequences, primer annealing temperature $\left(\mathrm{Ta}^{0}\right)$ and PCR product sizes were given in Table 1 . The PCR reaction was performed using following condition: $94^{0} \mathrm{C}, 5 \mathrm{~min}-$ utes, followed by 30 cycles of $94^{\circ} \mathrm{C}$ for 1 minute, $\mathrm{Ta}^{0}$ for respective primers (Table 1) for 1 minute, $72^{\circ} \mathrm{C}$ for 1 minute and followed by $72^{0} \mathrm{C}$ for 10 minutes for final extension. The amplified products were separated by electrophoresis on $1.5 \%$ agarose gel, stained with $0.5 \mathrm{mg} / \mathrm{ml}$ ethidium bromide, in $1 \mathrm{X}$ Tris Acetate EDTA buffer ( $\mathrm{pH}$ 8.0). The PCR products were visualized and photographed under UV transilluminator using a computer assisted image analysis program (UVP Doc. It ${ }^{\circledR}$ LS Image Analysis Software; version 6.3.3).

\section{Statistical Analysis}

Statistical analysis was done using Graph pad prism 6 (version 6.02) and Graph pad Instat 3 softwares.

\section{RESULTS}

Age

The analysis revealed that the overall mean age of the participants were $24.85 \pm 4.51$ years. The respective values among the cases and controls were found to be $24.88 \pm 4.97$ years $V s 24.83 \pm 4.05$ years with a statistically insignificant difference $(\mathrm{P}=.96)$.

\section{Socio Economic Status (Table 2)}

\section{Distribution of Infertile Patients According to Primary and Secondary Infertility}

$75 \%\left(\mathrm{n}_{1}=30\right)$ of cases were suffering from primary infertility and rest $\left(\mathrm{n}_{2}=10 ; 25 \%\right)$ from secondary infertility.

\section{Seropositivity of Chlamydia Trachomatis (Table 3, Table 4) \\ Result of PCR}

Test revealed relatively low and equal magnitude among pregnant $(2.5 \%)$ and infertile $(2.5 \%)$ women. Naturally there was no statistically significant difference between the two groups $(\mathrm{P}=1.0)$. Out of 80 samples 2 samples (I15 and P6) showed the production of amplicons that had base pairs of molecular weight 208bp with R1 - R2 primers (Fig. 1). Only 1 sample (I15) gave positive result with production of amplicons of 208bp, 280bp \& 208bp respectively with all the 3 primers used, i.e, R1 - R2 (Fig. 1), JM15 - JM16 (Fig. 2) \& CT0005 - CT06 (Fig. 3).

Based on results of serological tests and PCR total 7 $(8.75 \%)$ patients were diagnosed as infected. Among the 6 infected infertile patients, 4 were suffering from primary infertility and 2 from secondary infertility (Diagram 1).

There was no statistically significant difference in the infectivity rate between primary infertile (13.33\%) and secondary infertile $(20.00 \%)$ patients (Fisher's exact test, $p=$ $0.6287, \mathrm{OR}=0.615495 \% \mathrm{CI} 0.09449$ to 4.008$)$. The only infected pregnant woman was multigravida.

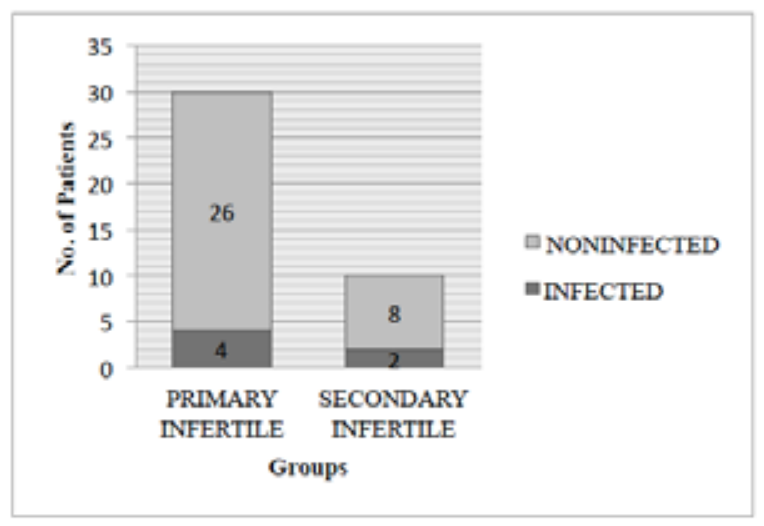

Diagram 1. Component bar diagram showing magnitude of Chlamydia trachomatis infection among primary and secondary infertile cases.

\section{DISCUSSIONS}

The significant difference in IgG seropositivity between cases and controls of present study is in agreement with the studies of Siemer et al., 2008 at Ghana [26] and Jeremiah et al., 2011 at Nigeria [27] who also found statistically significant difference between the IgG seroprevalence rate of infertile and pregnant women $(P<.001)$. Similar to the present study, Sharif et al., 2011 in Saudi Arabia also found no statistically significant difference in the $\operatorname{IgA}$ seroprevalence rates of cases and controls ( $25 \%$ vs $10 \%, P=.4)$ [28]. But, in contrary to the present study statistically significant difference was present in the $\operatorname{IgA}$ seroprevalence rate of infertile and pregnant women in the study of Siemeret al., 2008 (14\% vs $3 \%, P<.001)[26]$.

Table 1. Primer sequence and condition used for PCR method.

\begin{tabular}{|c|c|c|c|}
\hline Primer name & Primer sequence $\left(5^{\prime}-3^{\prime}\right)$ & Product size (bp) & $\mathbf{T a}^{0}$ \\
\hline СТ0005 - СТ06 $[22,23]$ & $\begin{array}{l}\text { CT0005 - 5' GAT AGC CAG CAC AAA GAG AG 3' } \\
\text { CT06 - 5' CTT TGT TTT CGA CCG TGT TTT 3' }\end{array}$ & 280 & $55^{\circ} \mathrm{C}$ \\
\hline JM15 - JM16 [23] & $\begin{array}{l}\text { JM15 - 5' TTG CTT GGA GTG CTG GACT 3' } \\
\text { JM16 - 5' TCC TTA GTT CCT GTC ACA CC 3, }\end{array}$ & 208 & $55^{\circ} \mathrm{C}$ \\
\hline
\end{tabular}




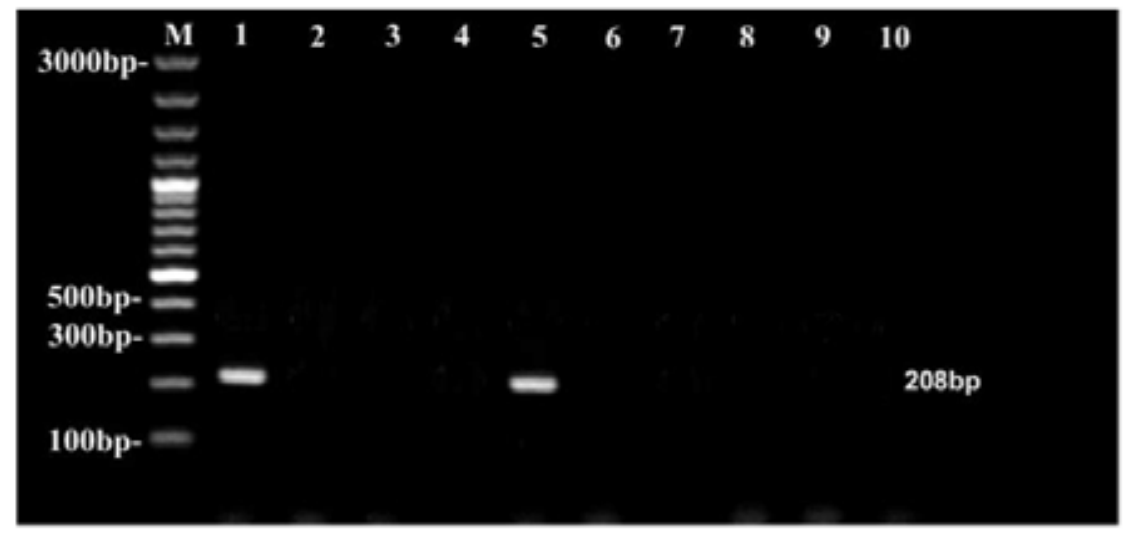

Fig. (1). Agarose gel electrophoresis of amplified products with R1 - R2 primer. DNA marker is in the left outside lane. Lane 1 (I15) and Lane 5 (P6) show amplified product of 208bp.

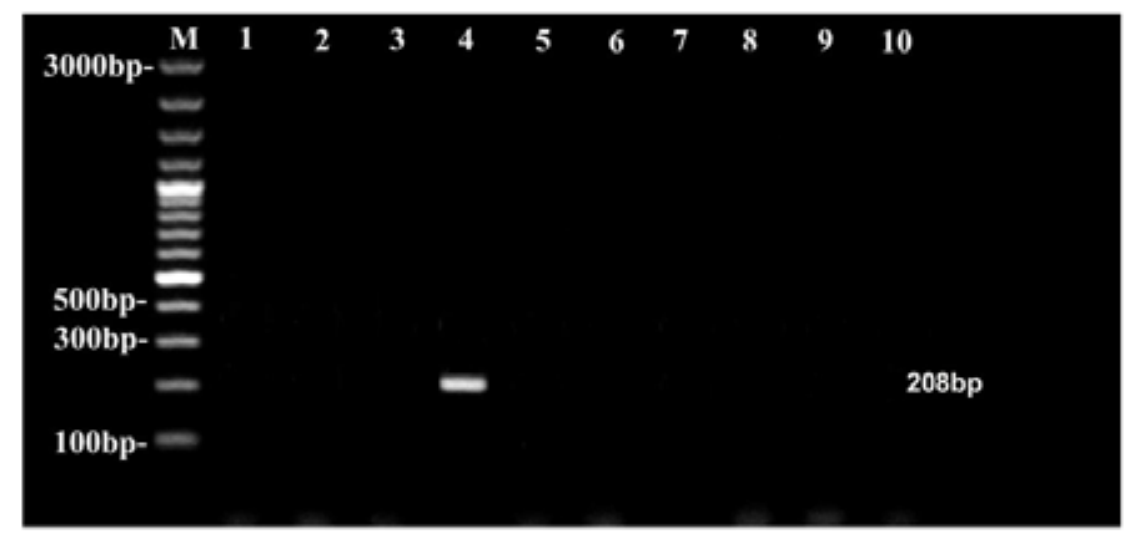

Fig. (2). Agarose gel electrophoresis of amplified products with JM15 - JM16 primer. DNA marker is in the left outside lane. Lane 4 (I15) shows amplified product of $208 \mathrm{bp}$.

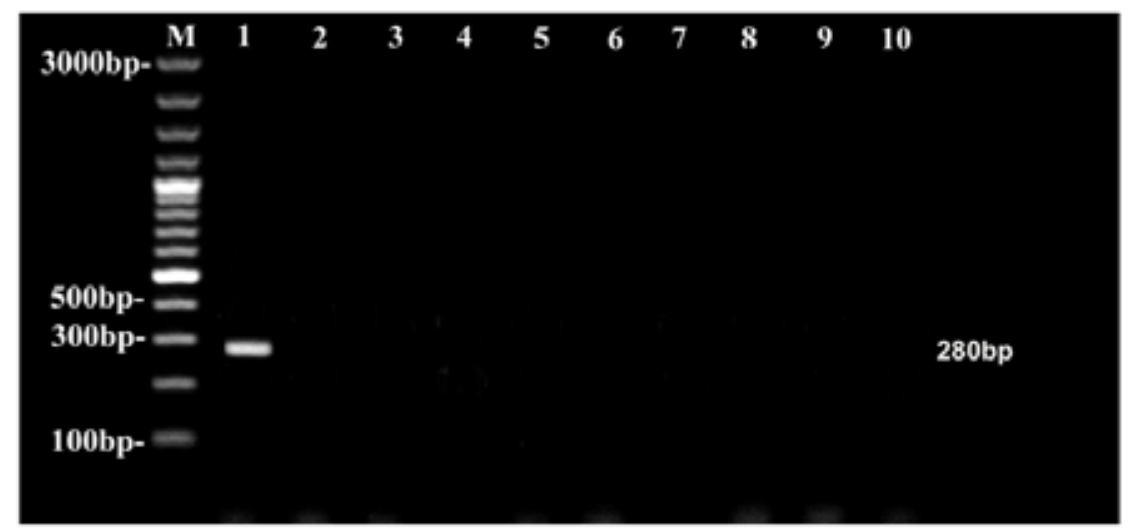

Fig. (3). Agarose gel electrophoresis of amplified products with CT0005-CT06 primer. DNA marker is in the left outside lane. Lane 1 (I15) shows amplified product of $280 \mathrm{bp}$.

The use of Nucleic acid diagnostic techniques such as polymerase chain reaction (PCR) has revolutionized our ability to diagnose almost all the microbes including genital tract Chlamydia trachomatis infection in minimum time with stringent specificity. Sensitivity and specificity of this test on FVU sample have been proven comparable to those obtained on samples collected directly from cervix or urethra [26]. Moreover, FVU sample collection is noninvasive, more acceptable to patients and does not require help of medical personnel to perform vaginal speculum examination which is needed to collect endo-cervical swabs. Sensitivity and specificity of PCR on urine samples are $87 \%$ and $99.8 \%$ respectively [29]. The lower PCR positivity rate and nonsignificant difference between infertile and pregnant groups is in agreement with several previous studies. Siemeret al., 2008 conducted a case control study in Ghana among 191 infertile and 248 pregnant women. PCR testing of FVU samples could not reveal any significant difference between the 2 groups (2.4\% vs $1.6 \%, P>$.05) [26]. Ramahiet al., 2008 at Jordan also found no significant difference $(P>.05)$ in PCR 
Table 2. Distribution of infertile and pregnant women as per different socioeconomic status (as per modified B. G. Prasad's scale, 2013) $[20](\mathbf{N}=\mathbf{8 0})$.

\begin{tabular}{|c|c|c|c|c|c|c|}
\hline Groups & $\begin{array}{c}\text { Class I } \\
\text { No. }(\%)\end{array}$ & $\begin{array}{c}\text { Class II } \\
\text { No. }(\%)\end{array}$ & $\begin{array}{c}\text { Class III } \\
\text { No. }(\%)\end{array}$ & $\begin{array}{c}\text { Class IV } \\
\text { No. }(\%)\end{array}$ & $\begin{array}{c}\text { Class V } \\
\text { No. }(\%)\end{array}$ & Total \\
\hline \hline $\begin{array}{c}\text { Infertile } \\
\left(\mathbf{n}_{\mathbf{1}}=\mathbf{4 0}\right)\end{array}$ & $3(7.5)$ & $18(45.0)$ & $9(22.5)$ & $10(25.0)$ & $0(0.0)$ & $40(100.0)$ \\
\hline $\begin{array}{c}\text { Pregnant } \\
\left(\mathbf{n}_{\mathbf{2}=\mathbf{4 0})}\right.\end{array}$ & $0(0.0)$ & $10(25.0)$ & $11(27.5)$ & $17(42.5)$ & $2(5.0)$ & $40(100.0)$ \\
\hline $\begin{array}{c}\text { Total } \\
(\mathbf{N}=\mathbf{8 0})\end{array}$ & $3(3.75)$ & $28(35.0)$ & $20(25.0)$ & $27(33.75)$ & $2(2.5)$ & $80(100.0)$ \\
\hline
\end{tabular}

*Chi square test performed. df: degree of freedom

Table 3. Distribution of participants as per their IgG seropositivity status $(\mathbf{N}=\mathbf{8 0})$.

\begin{tabular}{|c|c|c|c|c|}
\hline IgG & $\begin{array}{c}\text { Infertile } \\
{\left[n_{1}=40\right]} \\
\text { No }(\%)\end{array}$ & $\begin{array}{c}\text { Pregnant } \\
{\left[\mathrm{n}_{2}=40\right]} \\
\text { No }(\%)\end{array}$ & $\begin{array}{c}\text { Total } \\
{[\mathrm{N}=80]} \\
\text { No }(\%)\end{array}$ & $\begin{array}{c}\text { P [Fisher's exact test] } \\
\text { OR* }(95 \% \mathrm{CI})\end{array}$ \\
\hline Present & $6(15.0)$ & $0(0.0)$ & $6(7.5)$ & \multirow{2}{*}{$\begin{array}{c}0.02 \\
15.26(0.8290-280.9)\end{array}$} \\
\hline Absent & $34(85.0)$ & $40(100.0)$ & $74(92.5)$ & \\
\hline Total & $40(100.0)$ & $40(100.0)$ & $80(100.0)$ & \\
\hline
\end{tabular}

*OR: Odds Ratio, CI: Confidence Interval

*The above table shows that despite the significantly (as per Fisher exact test) higher rate of IgG seropositivity in the infertile group the difference was not shown to be statistically robust as per $95 \% \mathrm{CI}$ of OR. However, it was revealed to be significant at $90 \%$ confidence interval (90\% CI 1.324 to 175.8 ).

Table 4. Distribution of participants as per their IgA seropositivity status $(\mathbf{N}=\mathbf{8 0})$.

\begin{tabular}{|c|c|c|c|c|}
\hline IgA & $\begin{array}{c}\text { Infertile } \\
{\left[n_{1}=40\right]} \\
\text { No }(\%)\end{array}$ & $\begin{array}{c}\text { Pregnant } \\
{\left[n_{2}=40\right]} \\
\text { No }(\%)\end{array}$ & $\begin{array}{c}\text { Total } \\
{[\mathbf{N}=80]} \\
\text { No }(\%)\end{array}$ & $\begin{array}{c}\text { P [Fisher's exact test] } \\
\text { OR* }(95 \% \mathrm{CI})\end{array}$ \\
\hline Absent & $35(87.5)$ & $39(97.5)$ & $74(92.5)$ & $\begin{array}{c}0.2, \\
5.571(0.6201-50.06)\end{array}$ \\
\hline Total & $40(100.0)$ & $40(100.0)$ & $80(100.0)$ & 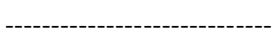 \\
\hline
\end{tabular}

*OR: Odds Ratio, CI: Confidence Interval

positivity tested on endocervical swab of 152 infertile $(3.9 \%)$ and 146 pregnant $(07 \%)$ women [30]. In another case control study of Muvunyiet al., 2011 at Rwanda, 303 infertile and 312 fertile women were investigated. PCR testing on vaginal swabs were performed. The PCR prevalence was relatively low and did not differ significantly between the 2 groups (3.3\% vs $3.8 \%, P>.05)$ [31]. But in contrary to the present study, Pramaniket al., 2012 at Mumbai, India could find significant difference in the PCR positivity rate between infertile and pregnant women $(P<0.0005)$ [32].

The present study demonstrated that sensitivity was higher with R1 - R2 primer than MOMP primers. It is in contrary to the study of Mahony et al., 1993, in which they found that the sensitivity of MOMP based PCR assay was better than rRNA DNA based PCR [23]. 16S ribosomal RNA genes contain highly conserved stretches of nucleotide sequences in a large group of microorganism. It is genus specific and more than $95 \%$ identical in Chlamydia trachomatis, Chlmydia psittaci and Chlamydia pneumoniae
[24]. So PCR with rRNA DNA is less specific than PCR assay targeting MOMP primer. But, in the present study, the pregnant woman (P6) who gave amplified products with R1$\mathrm{R} 2$ primer only was also $\operatorname{IgA}$ seropositive and $\mathrm{IgG}$ seronegative. Serum IgA is an indicator of active infection. The patient also had history of white discharge, dysmenorrhoea, chronic pelvic pain, menorrhagia and history of urethral discharge in partner suggesting presence of current sexually transmitted infection. So to conclude, the patient was currently infected with Chlamydia trachomatis. One major problem with PCR is the presence of potential inhibitors in clinical specimens that can lead to false negative results. Genital tract and urine specimens are known to contain several factors that inhibit DNA polymerase and the exact nature of all of the inhibitors remains to be defined [33].

When individuals acquire Chlamydial infection, there is a lag period/ time interval before antibody response. Similarly antibodies persist for a long time after an infection that is resolved by cellular immune response [33]. In the present 
study and also in the above mentioned studies IgG positivity was relatively higher than PCR. While serological tests cannot replace the sensitive and specific direct tests, they may be useful in identifying Chlamydial etiology in ascending upper genital tract infection, where direct tests may often fail to detect the presence of organism. As, chronic / persistent infection will induce an immune response and inflammatory reactions resulting in a cyclic process of scarring of the infected tissue leading to partial or total obliteration of the fallopian tubes causing tubal factor infertility or sub infertility $[4,12,17]$ persistence of serum antibodies are better predictors of infertility and a negative urine sample cannot exclude infection of upper genital tract infection. This corroborates with the study of Joyee et al., 2007 in Chennai, India, who also could not find any correlation between $\operatorname{IgG}$ positivity detected by immune-peroxidase kit and PCR from genital swabs in STD patients [34].

Based on the results of ELISA and PCR the proportion of this infection among all the study participants was $8.75 \%$, and among the infertile population was $15 \%$ in the present study. It was comparable to the cross sectional study of Pramaniket al., 2012 at Mumbai in India. The average infection rate was $12.1 \%$, highest in women with infertility $(18.6 \%)$ or with ectopic pregnancy (25\%). They used PCR to evaluate current infection and ELISA for IgG antibody against Chlamydia trachomatis to detect past infection. In contrary to the present study statistical analysis revealed significant association between current $C$. trachomatis infection with infertility when comparing infected fertile $(18.6 \% \mathrm{vs} .9 .4 \%$, odds ratio: $2.19, P<.0005)$ and uninfected infertile women (45.6\% vs. 27.3\%, odds ratio: $2.24, P<.0001$ ). They excluded women positive for $C$. trachomatis antibody from analysis as presence of $C$. trachomatis antibody is known to be associated with tubal factor infertility [32]. In another study Pratibha et al., 2010 in Chidambaram found much higher seroprevalence $(62 \%)$ in infertile women. Infection was found in $56 \%$ of primary infertility cases and $73 \%$ of secondary infertility cases [35]. From the literature, it is clearly evident that prevalence was higher in African countries [26, 27, 36] than South East Asian countries [19, 28, 30, 32]. According to WHO prevalence estimates there is vast difference in the prevalence in different geographical regions. 3.89 $\%$ females are infected in WHO African region, whereas only $1.09 \%$ females are infected in WHO South East Asian region in the year 2005 [1]. As in the present study infertile population is taken, the prevalence is higher than the general estimates. There is variation in the contribution of previous history of STDs with infertility. It has been considered lower among infertile population of Asia than Africa in different studies [37]. In the present study $13.33 \%$ of primary infertile women and $20.00 \%$ of secondary infertile women were infected. There was no statistically significant difference in the magnitude of infection between the 2 groups $(P=.6287$, OR $=0.6154,95 \%$ CI 0.09449 to 4.008$)$. Malik et al., 2006 in Aligarh found that Chlamydial positivity detected by endocervical swab culture and antigen detection was seen in $27 \%$ of women with primary infertility and $30.6 \%$ with secondary infertility. Though the prevalence was much higher, still there was no statistically significant difference between the proportions $(P=>.05)$ [19]. But in a community based study carried out in Saudi Arabia, Kamel Remah M, in 2013 found statistically significant $(P=.0096)$ higher prevalence of infection among primary (11.72\%) than secondary (3.28\%) infertile women [38]. Similar to the present study prevalence of infection was $13.33 \%$ among primary infertile women in the study of Deshmukh et al., 2013 in Maharashtra, India. But they also observed a statistically significant difference when $C$. trachomatis $\operatorname{IgG}$ positive patients were compared in respect to primary $v s$ secondary infertility (X2 -10.44 $P<.05)[39]$.

\section{CONCLUSION}

The proportion of Chlamydia trachomatis seropositivity (IgG and $\operatorname{IgA}$ ) was higher in infertile women than pregnant women, though there was no significant difference in PCR positivity between the 2 groups. So, persistent $C$. trachomatis infection must be recognized as a risk factor of infertility. The low PCR positivity in FVU sample further helps to conclude the diagnostic utility of serological tests in screening of infertile women.

\section{CONFLICT OF INTEREST}

The authors confirm that this article content has no conflict of interest.

\section{ACKNOWLEDGEMENTS}

The authors sincerely acknowledge the contribution of all the staffs of the Department of Microbiology, R. G. Kar Medical College, Kolkata and Department of Biochemistry, Institute of Post Graduate Medical Education \& Research, Kolkata.

\section{REFERENCES}

[1] World Health Organization. Prevalence and incidence of selected sexually transmitted infections, methods and results used by WHO to generate 2005 estimates. WHO 2011; pp.1-38. [Cited 2011 December 1]. Available from: http://www.who.int/reproductivehealth/ publications/rtis/9789241502450/en/

[2] Academy for Educational Development. Summary of a review of literature: programs to promote Chlamydia screening. AED 2007; pp. 1-35. [Cited 2011 December 1]. Available from: http://www.cdc.gov/std/HealthComm/ChlamydiaLitReview2008.p df.

[3] Charlotte GA, Thomas QC. Chlamydial Infections. In: Dan LL, Anthony FS, Dennis KL, Stephen HL, Jameson JL, Joseph L. Eds. Harrison's Principles of Internal Medicine. McGraw Hill 2012: pp. 1421-31.

[4] Walter SE, Byron BE. Chlamydia trachomatis (Trachoma, Perinatal Infections, LymphogranulomaVenereum, and other genital infections). In: Gerald ML, John BE, Rephael D, Eds. Mandell, Douglas \& Bennett's Principles \& Practice of Infectious Diseases.. Churchill Livingstone Else 2010: pp. 2443-57.

[5] Thomas K, Coughlin L, Mannion PT, et al. The value of Chlamydia trachomatis antibody testing as part of routine infertility investigations. Hum Reprod 2000; 15(5): pp. 1079-82.

[6] Mira A, Richard BO, Danny SJ, et al. Infertility and assisted reproductive technology. In: Jonathen BS, Ed. Berek \& Novak's Gynaecology. Lippincott William Wilk 2012; pp. 1133-89.

[7] World health Organization. Infecundity, Infertility and Childlessness in developing countries. DHS Comparative Reports no 9. Calverton, Maryland, USA: ORC Macro and the World Health Organization 2004 [Cited 2011 November 25]. Available from: http://www.who.int/reproductivehealth/topics/infertility/DHSCR9.pdf

[8] Paul AC, Krupp K, Alexandra FH, et al. Prevalence and correlates of primary infertility in Mysore, India. Ind J Med Res 2011; 440-6. 
[9] Srivastava P, Jha R, Bas S, et al. In Infertile women, cells from Chlamydia trachomatis infected site release higher levels of interferon gamma, interleukin 10, and tumor necrosis factor alpha, upon heat shock protein stimulation than fertile women. Reprod Biol Endocrinol 2008. [Cited 2011 January 5]. Available from: http://www.rbej.com/content/6/1/20.

[10] William GM. Duration of untreated uncomplicated Chlamydia trachomatis genital infection and factors associated with Chlamydia resolution: a review of human studies. J Infect Dis 2010; 201(S2): S104-13.

[11] Byron BE, Xu F, Robert JE, et al. Protective immunity to Chlamydia trachomatis genital infection: evidence from human studies. $\mathbf{J}$ Infect Dis 2010; 201(S2): S178-89.

[12] Toni D, Thomas HJ. Pathogenesis of genital tract disease due to Chlamydia trachomatis. J Infect Dis 2010; 201(S2): S114-25.

[13] Witkin SS, Jeremias J, Neuer A, et al. Immune recognition of the $60 \mathrm{kD}$ heat shock protein: implications for subsequent fertility. Infect Dis Obstet Gynecol 1996; 4: 152-8.

[14] Mardh PA. Chlamydia. In: Peter BS, Patrick MR, Guido F, Eds. Topley \& Wilson's Microbiology \& Microbial Infections. Hodder Arnold 2005: 2006-25.

[15] Paavonen J, Kruse WE. Chlamydia trachomatis: Impact on human reproduction. Hum Reprod 1999; 5(5): 433-47.

[16] Hartog JE. den, Land JA, Stassen FRM, et al. Serological markers of persistent $C$. trachomatis infections in women with tubal factor subfertility. Hum Reprod 2005; 20(4): 986-90.

[17] Sami GL, Robert BC, Gerald BI, et al. Introduction: The natural history and immunobiology of Chlamydia trachomatis genital infection and Implications for Chlamydia control. J Infect Dis 2010; 201(S2): S85-7.

[18] Fleiss JL, Levin B, Paik MC. Statistical Methods for Rates and Proportions. $3^{\text {rd }}$ ed. New York John Wiley \& Sons 2003.

[19] Malik A, Jain S, Hakim S, et al. Chlamydia trachomatis infection and female infertility. Ind J Med Res 2006; 123: 770-5.

[20] Dudala SR, Arlappa N. An Updated Prasad's Socio Economic Status Classification for 2013. Int J Res Dev Health 2013; 1(2): 26-7.

[21] Fallah F, Kazemi B, Goudarzi H, et al. Detection of Chlamydia trachomatis from urine specimens by PCR in women with cervicitis. Iran J Public Health 2005; 34(2): 20-6.

[22] Linda B, Francois C, Robert YH, et al. Diagnosis of Chlamydia trachomatis Cervical infection by detection of amplified DNA with an enzyme immunoassay. J Clin Microbiol 1990; 28(9): 1968-73.

[23] James MB, Kathy LE, John SW, et al. Comparison of plasmid and chromosome based polymerase chain reaction assays for detecting Chlamydia trachomatis nucleic acids. J Clin Microbiol 1993; 31(7): 1753-8.

[24] Claas HC, Melchers WJ, Bruijn IHde, et al. Detection of Chlamydia trachomatis in clinical specimens by the polymerase chain reaction. Eur J clin Microbiol Infect Dis 1990: 864-8.
[25] Claas HCJ, Wagenvoort JHT, Niesters HGM, et al. Diagnostic Value of the polymerase chain reaction for Chlamydia detection as determined in a follow up study. J Clin Microbiol 1991; 29(1): 425 .

[26] Jorn S, Oliver T, Yaw L, et al. Chlamydia trachomatis infection as a risk Factor for infertility among women in Ghana, West Africa. Am J Trop Med Hyg 2008; 78(2): 323-7.

[27] Israel J, Ola O, Chris A. The prevalence of serum immunoglobulin $\mathrm{G}$ antibody to Chlamydia trachomatis in subfertile women presenting at the University of Port Harcourt Teaching Hospital, Nigeria. Int J Biomed Sci 2011; 7(2): 120-4.

[28] Fadwa SM Al. Detection of Chlamydia trachomatis among infected women. Aus J Basic Appl Sci 2011; 5(8): 795-802.

[29] Paz-Bailey G, Rahman M, Chen C, et al. Changes in the etiology of sexually transmitted diseases in Botswana between 1993 and 2002: implications for the clinical management of genital ulcer disease. Clin Infect Dis 2005; 41(9): 1304-12.

[30] Al-Ramahi M, Mahafzah A, Saleh S, et al. Prevalence of Chlamydia trachomatis infection in infertile women at a university hospital in Jordan. East Mediterranean Health J 2008; 14(5): 1148-54.

[31] Muvunyi MC, Dhont N, Verhelst R, et al. Chlamydia trachomatis infection in fertile and subfertile women in Rwanda: prevalence and diagnostic significance of $\mathrm{IgG}$ and $\mathrm{IgA}$ antibodies testing. Hum Reprod 2011; 26(12): 3319-26.

[32] Mania PJ, Shilpa K, Shobha S, et al. Current Chlamydia trachomatis infection, a major cause of Infertility. J Reprod Infertil 2012; 13(4): 204-10.

[33] Hamdad DF, Jacues P, Francois E. Assessment of Chlamydia trachomatis infection in asymptomatic male partners of infertile couples. J Med Microbiol 2004; 53: 985-90.

[34] Joyee AG, Thyagarajan SP, Reddy EV, et al. Diagnostic utility of serologic markers for genital Chlamydial infection in STD patients in Chennai, India. J Assoc Phys India 2007; 55: 777-80.

[35] Pratibha G, Joseph PID. Incidence of Chlamydia trachomatis infection in infertile urban population. J Ecobiotechnol 2010; 2(3): 7-11.

[36] Mawak JD, Dashe N, Agabi YA, et al. Prevalence of genital Chlamydia trachomatis infection among gynecologic clinic attendees in Jos, Nigeria. Shiraz E-Med J 2011; 12(2): 100-6.

[37] Shireen JJ. Infertility in India-levels, patterns and consequences: priorities for social science research. J Fam Welf 1998; 44(2): 1524.

[38] Remah KM. Screening for Chlamydia trachomatis infection among infertile women in Saudi Arabia. Int J Women's Health 2013; 5 : 277-84.

[39] Deshmukh DG, Bajaj JK, Damle AS, et al. Study of Chlamydia trachomatis in infertile women. Paripex Ind J Res 2013; 2(3): 2603.

Received: December 31, $2014 \quad$ Revised: June 19,2015

Accepted: June 22, 2015

(c) Ghosh et al.; Licensee Bentham Open.

This is an open access article licensed under the terms of the Creative Commons Attribution Non-Commercial License (http://creativecommons.org/licenses/by-nc/3.0/) which permits unrestricted, non-commercial use, distribution and reproduction in any medium, provided the work is properly cited. 